Reporting Date: June 1975 Issued: September 1975

\title{
A New Method for
}

Coating Microspheres with Zirconium Carbide and Zirconium Carbide-Carbon Graded Coats

by

C. M. Hollabaugh

R. D. Reiswig

P. Wagner

L. A. Wahman

R. W. White

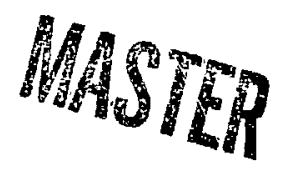

An Affirmative Action/Equal Opportunity Employer 
This work was supported by the Gas Cooled Reactor Project of the Division of Feactor Research and Development, US Energy Research and Development Administration.

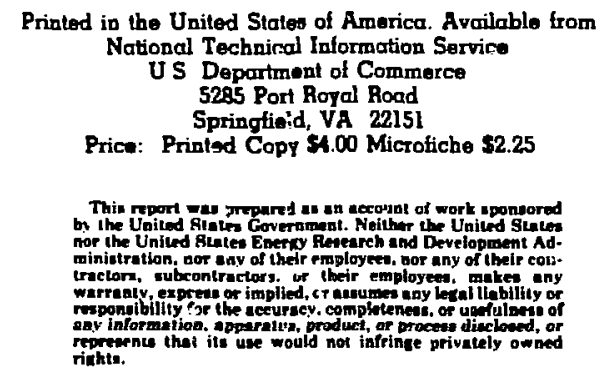




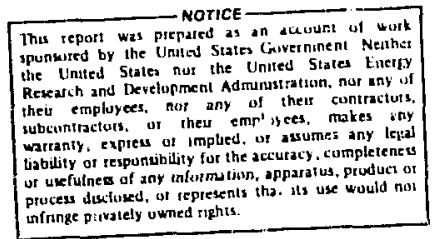

A NEW METHOD FOR COATING MICROSPHERES WITH ZIRCONIUM CARBIDE AND ZIRCOHIUM CARBIDE-CARBON GRADED COATS

by

C. M. Hollabaugh, R. D. Reiswig, P. Wagner, L, A, Wahman, and R. W. White

\section{ABSTRACT}

A new method for the chemical vapor deposition of $\mathrm{ZrC}$ and $\mathrm{C}-\mathrm{ZrC}$ alloys has been developed. This process las been applied to the fabricat ion of coated particle nuclear fuels of the type used in the large High-Temperature Gas-Cooled Reactor. A powder feeder is used to supply $\mathrm{ZrCl}_{4}$ to the fluidized bed coating furnace where it undergoes reaction with ${ }^{4}$ hydrocarbon to form $\mathrm{ZrC}$. Quant $L$ tat ive metering of the $\mathrm{ZrCl}_{4}$ makes it possible to control the deposition of the $\mathrm{ZrC}$ and the codeposition of the C-zrC alloys on the fuel particles.. Examples of both types wf coats made using the described technique are discussed and illustrated.

\section{INTRODUCT ION}

During the past few years several papers on the chemical vapor deposition of zirconium carbide, and ZrC-carbon alloys ${ }^{1-11}$ have appeared in the literature. Techniques for $\mathrm{ZrC}$ coating of surfaces of massive bodies, ${ }^{4-6}$ for preparing low thermal expansion substrates of macrodimensions, 11 and for coating microspheres which are hundreds of micrometers $(\mu \mathrm{m})$ in diameter ${ }^{1-3,7-10}$ have been described in varying degrees of detail. This report describes a method whose description has not appeared in the literature and whose capabilities span many of the likely applications of chemically vapor deposited $\mathrm{ZrC}$ and $\mathrm{ZrC}-\mathrm{C}$ alloys.

The area of particular interest is that concerned with the fissile fuel particles used in the large High-Temperature Gas-Cooled Reactor. These particles are of the TRISO design. ${ }^{12}$ In the TRISO fissile fuel particles, a $U_{2}$ or $\mathrm{UO}_{2}$ kernel (- 200um-diam) is coated with low-density pyrolytic carbon of nominal 85 um thickness using a fluidized bed chemical vapor deposition process. This, in turn, is covered by a 25- $\mu m$ layer of an isotropic pyrolytic carbon freferred to as LTI because of the relatively low temperature of deposition). Ihe LTI coat has depostted upon it a $25-$ wn layer of SiC and upon this another LII coat which is $35 \mu$ m in thickness. The method described in this report is used in making particles which are nominally of the TRISO design but that have a $\mathrm{ZrC}$ coat in place of the SiC layer. This method is also used to fabricate particles where the LTI-SIC-LTI layers can be replaced by a C-ZrC graded coat, a layer of $\mathrm{ZrC}$ and a $\mathrm{ZrC}-\mathrm{C}$ graded coat, or some other combination.

The interest in codepositing $\mathrm{ZrC}$ and LTI coats has been stimulated by the possibility of making fi:el particles with improved thermal and irradiation performance using a simpler coating process than that now used in the TRISO partiele manufacture. With a controllable codeposition process, a continuously graded coat can be made that starts out as pure LTI and has $2 \mathrm{rC}$ added in ever increasing amounts (by reaction of $\mathrm{ZrCl}_{4}$ with a hydrocarbon) until pure $\mathrm{ZrC}$ is deposited. The process can then be reversed and the $2 \mathrm{rc}$ decreased to get back to the LTI. The stress, which is generated by a mismatch of the thermal expansion coefficients of the components in the TRISO design, would be minimized in such a coat. Such a process could be a single step in the fabrication and could be used as a substitute for the three separate steps now used if. fabricating the outermost layers of the TRISO-type coated 
particles. Other advantages to a graded coat could be a reduction of the irradiation-induced creep in the LTI with a subsequent decrease in the creepinduced stresses in the three outermost coats (one of the causes of coat fallure at high fluence). Another favorable factor would be to reduce the magnitude of the physical properties mismatch achleved by the graded coat. A recent art $1 \mathrm{cle}{ }^{9}$ reported that the 2 rC-C composite (sometimes called zirconium carballoy or $\mathrm{C}-\mathrm{ZrC}$ alloy) is expected to have a higher mechankal strength, ${ }^{13}$ to have better thermal shock resistance than pure pyrolytic carbon, ${ }^{14}$ and to be better than stoichlometric $\mathrm{ZrC}$ from viewpoints of neutron economy and radiation damage. ${ }^{15}$ In addition to these advantages in the use of $\mathrm{zrC}$, temperature limits on fuel element fabrication, attributable to the SiC in coated particles, are removed when the $\mathrm{ZrC}$ is used. 16

These Ideas are neither new nor original, but they have not been implemented in the past because of the lack of quantitative control of the feed of the zirconium salt. This has been the chief impediment in the $\mathrm{ZrC}$ coating process and the major obstacle to developing a successful and controllable process for codepositing the zirconium carballoy. The Los Alamos Scientific Laboratory (LASL) has solved this problem by using an auger-type $\mathrm{ZrCl}_{4}$ powder feeder. The solid $\mathrm{ZrCl}_{4}$ feed rate is controlled by a dc motor-driven auger and the powder blown by an inert gas stream directly into the hot fluidized-bed inating furnace where it is volatilized. This method has proved to be predictable, controllable, and reproducible for fabricating the $\mathrm{ZrC}$ and $\mathrm{ZrC}-\mathrm{C}$. graded coats on the fluidized bed microspheres.

\section{DISCUSSION}

$\mathrm{ZrC}$ and $\mathrm{rC}-\mathrm{C}$ composites are made by reaction of a zirconiun halide with a hydrocarbon gas. The general system may be considered in terms of the following overall reactions.

$$
\begin{aligned}
& 2 \mathrm{rCl}_{4}(\mathrm{~g})+\mathrm{CH}_{4}(\mathrm{~g})=\mathrm{ZrCl}(\mathrm{s})+4 \mathrm{HCl}(\mathrm{g}) \\
& 2 \mathrm{rCl}_{4}(\mathrm{~g})+1 / 2 \mathrm{H}_{2}(\mathrm{~g})=2 \mathrm{rCl}_{3}(\mathrm{~g})+\mathrm{HCl}(\mathrm{g}) \\
& 2 \mathrm{rCl}_{3}(\mathrm{~g})+1 / 2 \mathrm{H}_{2}(\mathrm{~g})=2 \mathrm{rCl}_{2}(\mathrm{~g})+\mathrm{HCl}(\mathrm{g}) .
\end{aligned}
$$

Wallace ${ }^{4}$ proposed that the rate of $2 r C$ formation may be written as

$$
\frac{d(2 r C)}{d t}=\left(P_{\text {salt }} P_{\mathrm{CH}_{4}} P_{\mathrm{H}_{2}}^{1 / 2(n-2)} / \mathrm{P}_{\mathrm{HCl}}^{\mathrm{n}}\right) \mathrm{Ae}^{-\mathrm{B} / \mathrm{T}} \text {, }
$$

where

$$
\begin{aligned}
P_{\text {salt }} & =\mathrm{P}_{2 \mathrm{rCl}_{4}}+\mathrm{P}_{\mathrm{ZrCl}_{3}}+\mathrm{P}_{\mathrm{ZrCl}_{2}} \\
\mathbf{n} & =\left(4 \mathrm{P}_{\mathrm{ZrCl}_{4}}+3 \mathrm{P}_{\mathrm{ZrCl}_{3}}+2 \mathrm{P}_{\mathrm{ZrCl}_{2}}\right) / \mathrm{P}_{\text {salt }}
\end{aligned}
$$

and

A, B are constants.

Wallace further suggested that the rate-determining step is the reduction of the balide at the surface

$$
2 \mathrm{rCl}_{n}(g)+n / 2 \mathrm{H}_{2}(g)=(2 \mathrm{r})_{\text {surface }}+n \mathrm{HCl}(g) .
$$

If the problem to be solved in the $2 \mathrm{rC}$ deposition is really identifiable with the control of the pressure of the chemically sensitive components, then Wallace's analysis makes sense in terms of the past difficulties encountered by investigators in trying to deposit $\mathrm{ZrC}$ in a reproducible and controllable manner. $\mathrm{ZrCl}_{4}$ is a solid at room temperature, it has is sublimation temperature of $331^{\circ} \mathrm{C}$, and the problem of accurate metering of the $\mathrm{ZrCl}_{4}$ as a gas near this temperature is formidable.

The problem of delivering $2 \mathrm{rCl}_{4}$ gas to a reaction vessel has been appraached in a variety of ways. One method thet has been used is the reactor technique. This is shown In Fig. 1, schematically, for the formation of the $\mathrm{ZrCl}_{4}$ (other halides have al so been used). A gas such as $\mathrm{Cl}_{2}$ or $\mathrm{CH}_{2} \mathrm{Cl}_{2}$ is passed. over a bed of zirconium sponge kept at a temperature near the sublimation temperature of the $\mathrm{zrCl}_{4}$. The gaseous reaction froduct is then swept into the reaction vessel and mixed with the other reactant gases. Reynolds ${ }^{10}$ and Ikawa ${ }^{1}$ have used this method for the deposition of $2 \mathrm{rC}$ coats on microspheres. Ikawa has published several articles ${ }^{2,3,7-9}$ on the application of the reactor technique for preparation of codeposited carbon-zirconium carbije composites (zirconium carballoys).

Another method that has been used is shown schematically in Fig. $i$. In this technique, the $2 \mathrm{rCl}_{4}$ 


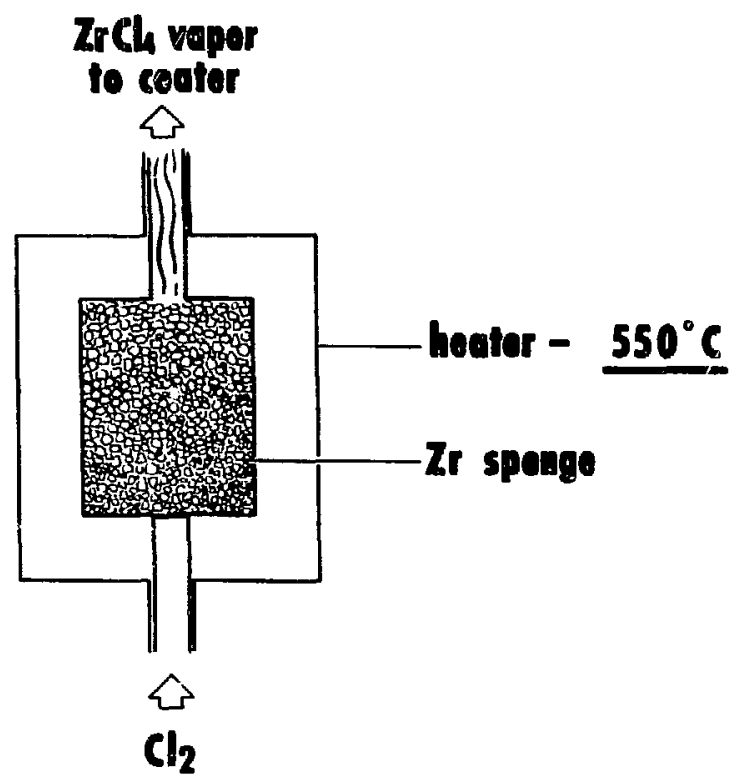

Fig. 1. $2 \mathrm{rCl}_{4}$ reactor.

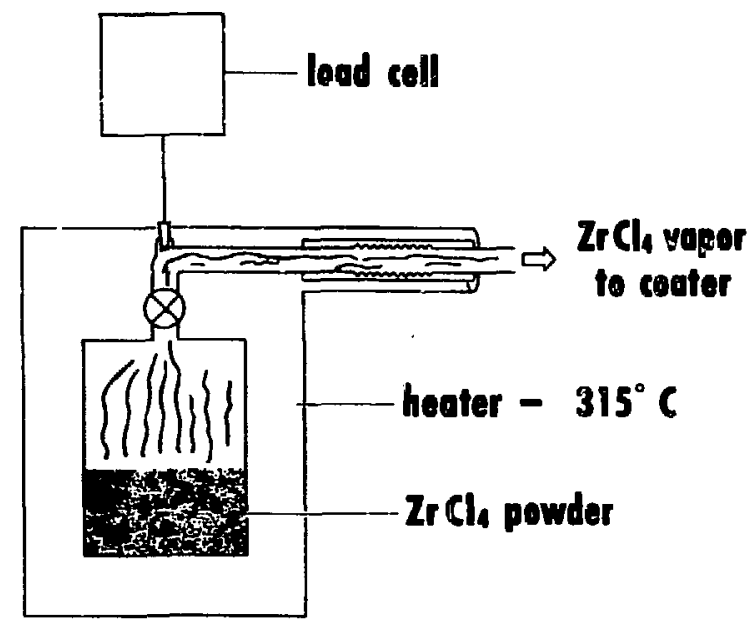

Fig. 2. $2 \mathrm{rCl}_{4}$ vaporizer.

is kept near its sublimation temperature and the evolved gas swept by an inert gas stream into the reaction chamber. Wallace has used this method for production of 2 rc-coated coolant channels in nuclear fuel elements ${ }^{4}$ and for fabrication of lowdensity $\mathrm{ZrC}$ fiber insulators. ${ }^{5,6}$ This is also the method used in the fabrication of low coefficient of the rmal-expansion (F,TE) carbon-zirconium carbide

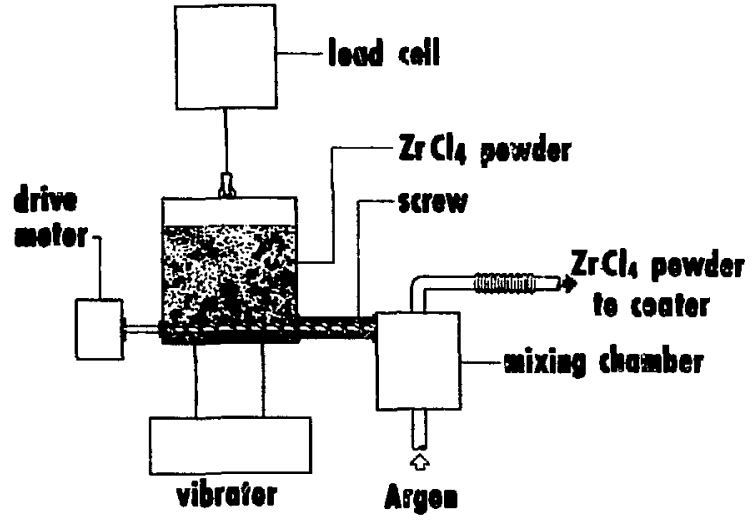

Fig. 3. $2 \mathrm{rCl}_{4}$ powder feeder.

composites which were used as substrates for materials in which the mismatch in the CTE's of adjacent graphite layers were to be minimized. ${ }^{11}$ In this method, the flow rate of the $\mathrm{ZrCl}_{4}$ is affected by the condition of the $\mathrm{ZrCl}_{4}$ solid (1.e., exposed surface area), the relation of the sweep gas velocity to the surface accessibility of the salt, the cooling effects of the sweep gases, the effect of the sublimaition rate of the $\mathrm{ZrCl}_{4}$ on the temperature of the solid, and the temperature of the solid $\mathrm{ZrCl}_{4}$ itself. This method has been used at LASL in the past for fluidized bed coating of microspheres. It was, however, the awkwardness of this system that supplied the impetus for the development of the $\mathrm{ZrCl}_{4}$ powder feeder method that is described in this report.

The desigr of the $\mathrm{ZrCl}_{4}$ powder feeder is shown in Fig. 3. The entire unit is maintained at ambient temperature. The hopper is purged of air, loaded with $2 \mathrm{rCl}_{4}$ powder in argon, and attached to the cozting furnace with a flexible tube. The vibrator shakes the $\mathrm{ZrCl}_{4}$ powder on to the auger, and the load cell output record yields the powder feed rate in terms of weight per unit time. As the powder is fed into the mixing chamber, it is entrained by the argon into the fluidized bed coating furnace. Just before the $\mathrm{ZrCl}_{4}$ powder enters the coating furnace, the other gaseous components $\left(\mathrm{Ar}, \mathrm{H}_{2}, \mathrm{CH}_{4}\right.$, or $\left.\mathrm{C}_{3} \mathrm{H}_{6}\right)$ are added. The $\mathrm{ZrCl}_{4}$ vaporizes in the coating furnace, the mass of the $z_{1}: 1_{4}$ is small compared to the mass of the heated furnace materials, and the energy uptake during the sublimation process is 
relatively insignificant and does not. cause temperature fluctuationg in the flufdized bed.

Conditions under which the coatings are applited are derived frot two basic factors. First, the overall gas dynamics and fumace charge (materials to be coated) must be matched to the furnace dimensions so that proper agitation and fluidization of the bed is achfeved. Second, the gas composition and temperature must be selected to yleld the destred coating rate and coat composition. The simplest zircontum-containing coat to consider Is the pure $\mathrm{ZrC}$. Once the coating batch weight, gas veloctty, and composition have been establishec, the auger speed to the $\mathrm{ZrCl}_{4}$ powder feeder is set to vield a $\mathrm{ZrCl}_{4}$ flow to aliow the reaction [see Eq. (1)] to proceed. Pure $\mathrm{ZrC}$ is normally deposited from a gas stream that is substodchlometric in hydrocarbon ${ }^{4}$ to prevent codeposition of carbon in the $\mathrm{ZrC}$. The auger speed is set to optimize the $\mathrm{C} / \mathrm{Zr}$ ratio in the gas stream, in order to avoid the codeposition problem and to yfeld the most desirable ZrC deposit.

Production of a graded C-ZrC coat is a far more complex situation. Here, where one wants to start with one pure constituent and to change the composition of the coat gradually until the serond component is deposited in the pure state, effective control of the hydrocarbon gas and the $\mathrm{ZrCl}_{4}$ gas is an absolute requirement. Establishnent of the batch weight, gas velocity, and composition to produce a particular coat composition must be done for all compositions in a graded coat - from the pure carbon through the C-ZrC alloy and into the pure $\mathrm{ZrC}$, or in whatever order is required. Propylene $\left(\mathrm{C}_{3} \mathrm{H}_{6}\right)$ is used to produce pure carbon coats and to provide the carbon for the graded portion of the codeposited carbon and ZrC. Methane is used with $2 \mathrm{rCl}_{4}$ for depositing pure $2 \mathrm{rC}$. A typical composition starts with an argon and $\mathrm{C}_{3} \mathrm{H}_{6}$ mixture that will deposit an isotroplc pyrolytic carbon coat. This is then changed to an argon, $\mathrm{H}_{2}, \mathrm{C}_{3} \mathrm{H}_{6}$, and $\mathrm{ZrCl}_{4}$ mixture in proportions to yield a cudeposit containing very little $\mathrm{ZrC}$. To increase the $\mathrm{ZrC}$ concentration, the $\mathrm{C}_{3} \mathrm{H}_{6}$ flow is reduced gradually until pure $\mathrm{ZrC}$ is deposited. At this point, $\mathrm{CH}_{4}$ is substituted for the $\mathrm{C}_{3} \mathrm{H}_{6}$. When the desired thickness of $\mathrm{ZrC}$ has been deposiced, the process is reversed. The $\mathrm{CH}_{4}$ flow is stopped and the $\mathrm{C}_{3} \mathrm{H}_{6}$ flow
Is stated and gradually increased to reduce the ZrC content of tie codeposited coat. Finally, the coating process is completed by shutting of $f$ the $2 \mathrm{rCl}_{4}$ and $\mathrm{H}_{2}$, and a pure isotroplc carbon coat is deposiced frow the $\mathrm{Ar}^{-\mathrm{C}_{3} \mathrm{H}_{6}}$ gixeure.

The composition gradient in the graded portion of the coat is controlled by time and coatiog rate for each composition. Since the coating is done on a sphere that grows with the coating, coating rates are defined as volumetric rates rather than by the conventlonal time-rate of change of thickness. The volumetric coating rate is assumed to be independent of thickness. It has been established that the coating rate changes almos: "I nearly wh propylene gas firw in the $\mathrm{C}-2 \mathrm{rC}$ composition range Investigated. As the volume of the microsphere changes and the $\mathrm{C}_{3} \mathrm{H}_{6}$ gas flow is changed to change the $\mathrm{C} / \mathrm{ZrC}$ ratio, these changes must be factored into the coating rate calculactons co ensure gradient unfformity.

\section{RESULTS}

Figures 4 through 7 are photomicrographs of particles made by using the equipment and the techniques described in this report. Figure 4 is a bright field photomicrograph of a TRISO-design 12 soated particle where the ceramic coat is ZrC rather than the $\mathrm{SiC}$ which is used in the cormercial reactor fuels. The kernel has been soated with a low-density pyrolytic caxton made by using acetyiene, and this is overcoated with a low-temperature isotropic pyrolytic carbon (LTI) made by using propylene. The $\mathrm{ZrC}$ coat was made by the reaction of Eq. (1), and the outermnst coat is an LTI made as before. The $\mathrm{ZrC}$ appears fully dense and shows no fincluatons, cracks, or laminations.

Figures 5, 6, and 7 show C-ZrC alloys of various types. Figure 5 is a photomicrograph of a $\mathrm{H}^{+}$etched coated particle in which the LTI coat is blended Into the $\mathrm{ZrC}$ coat In a serles of steps where the $\mathrm{ZrC}$ content is increased (moving outward from the particle kernel) until the coat is pure $2 r$. (this appears white in the photomicrographs). The fropylene flow was then increased in a series of steps to make layers with decreasing concentrafions of $\mathrm{zrC}$ in a C-ZrC alloy. The $\mathrm{H}^{+}$ecching brings out detalls of the different alloys (these etch at different rates and the resultant surfaces reflect 


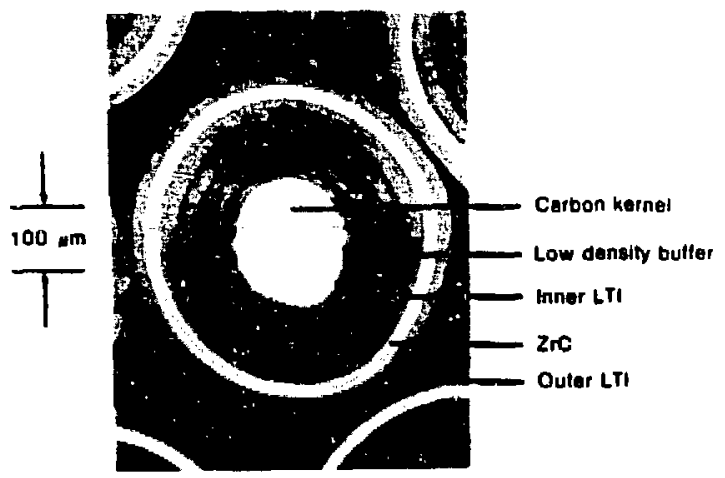

Fig. 4. TRIs0-type conted particle with ZrC.
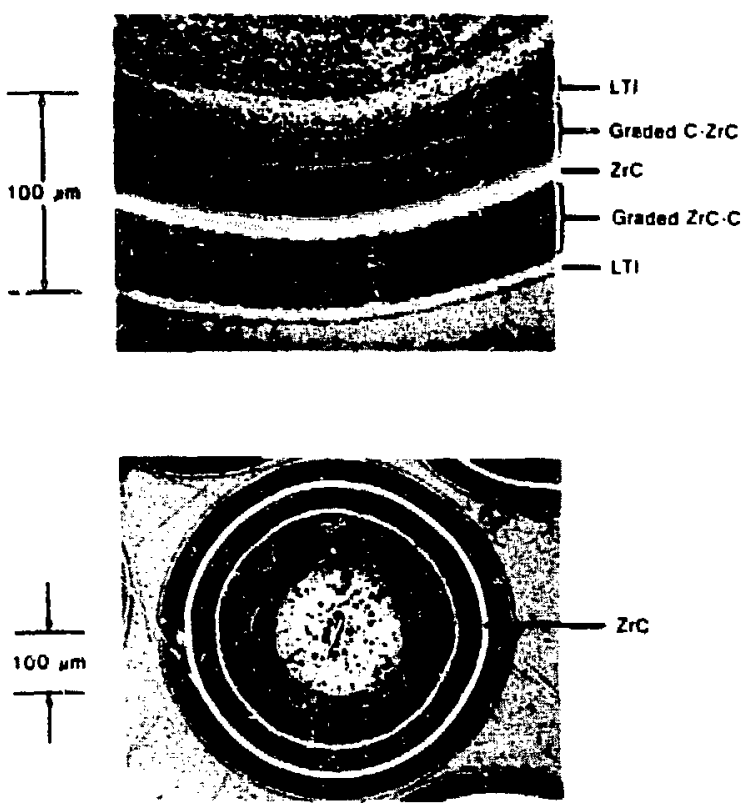

Fig. 5 Coated particle with graded C-2rC-C alloy coat. Layers in the coat are due to compositional differences.

differently), and are been discrete coats in FiB. 5. It is to be noted that the degree of blackening on the photomicrographs and the zrC content are not directly correlated. In E1g. 5, the $\mathrm{ZrC}$ content in the graded cost is symetric sbout the pure Zrć coat.

Figure 6 shows an example of a C-2rC alloy coat in which the graded coat starts at the outer surface of the lou-density pyrolytic carbon and the $2 \times \mathrm{C}$ concentration Increases with radius untd the pure $\mathrm{ZrC}$ coat has been deposited. In this example, the steps arf finer than thoge geen In Fig. 5, that 18, the differences between alloy compostt lons in adjolning

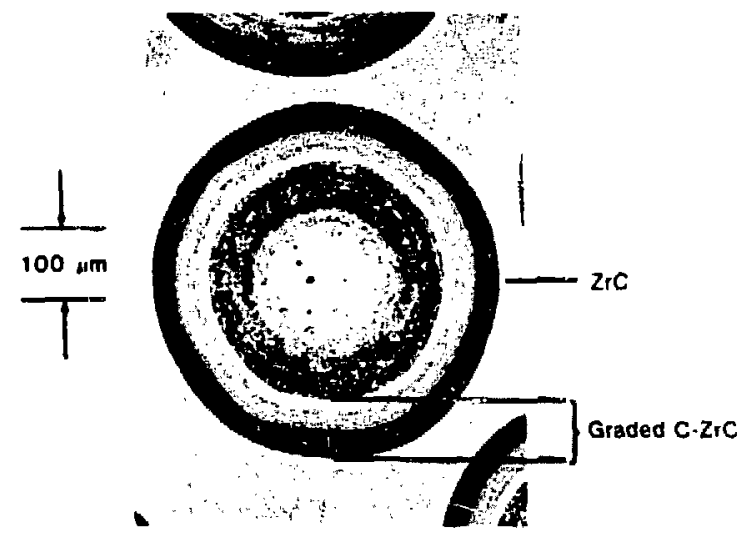

F18. 6. Coated particle uith graded C-2rC alloy coat. The graded coat has different composit lons although $1 t$ appears to be nearly continuous.
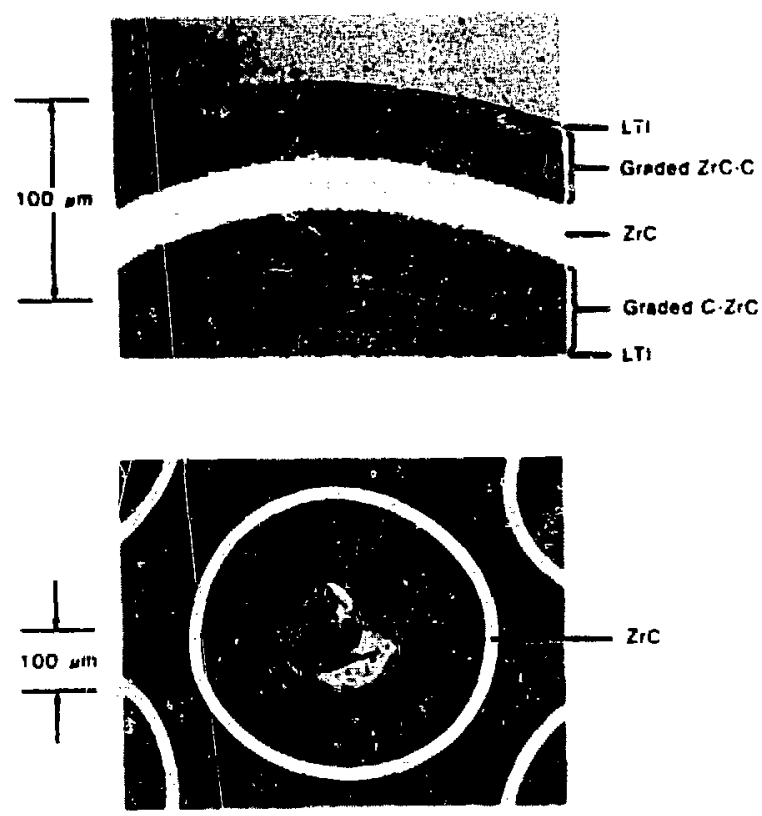

F18. 7. Coated particle with graced C-2rC-C alloy coat. The graded coats contain mote than one hundred alloy composiclons and appear continuous.

coats and the thickness of the Individual layers is small enough that they blend into one anocher.

Figure 7 is a photomicrograph of a coated particle which his the low-density buffer, then a graded C-2rC coat that stares out as a low-temperature lsotropic coat and has a gradually increasing 2 rC content, a pure Zrc layer, a graduaily decreasing zrc content, and finally, an outermoot thin layer 
of the LIT. I.n chis exarple, wre than a hundred different gas stream cosbinations of $\mathrm{C}_{3} \mathrm{H}_{6}$ and $\mathrm{ZrCl}_{4}$ vere ugad to deposit the graded coat.

\section{Iv. SUMMARY}

A technique for mak1ng $2 \pi \mathrm{C}$ coats has been described in which the $\mathrm{ZrCl}_{4}$ is supplied at amblent teaperat ure to a hot fluldized bed by an augerdriven powder feeder. The control of the $\mathrm{2rCl}_{4}$ llow is achloved by the auger speed. The $\mathrm{ZrCl}_{4}$ is vaperizud in the coacing furnace and reacts with a hydrocarbon species to form the carbide. By altering the rat 10 of the $\mathrm{C} / \mathrm{zr}$ atows in the coat $1 \mathrm{ng}$ chamber. It 18 possible to make coats of different C-zrc compositions. This his: been demonstrated by fabricating C-zrc alloys in which the C/Zr rat los are aleered with a resultant alteration in the character of the depoolt as seen in the $\mathrm{H}^{+}$etched photomicrographs.

Development of the pouder feeder has been the key to making predictable and reproducible coatings of $\mathrm{ZrC}$ and $\mathrm{C}-\mathrm{Z}=\mathrm{C}$ alloys. Coars made using this apparatus deposit readily in the furnace, unlforwity of the product is good, and tallograplote examination of the pure $2 \mathrm{rC}$ indicates that it is free of inclusions, cracks, pores, or other flaws. Examination of the C-ZrC graded alloys using the electron microprobe has indicated that systemutic changes In the gas stream composition results in corresponding changes in the concentration of $2 \mathrm{rc}$. As deposited, the $2 \mathrm{r} C$ has a diffuse $x$-ray diffraction pattern. Upon heat treacment to $1800^{\circ} \mathrm{C}$, this changes to a sharper fattern with a latice parameter of $4.6983: 3 \AA$. It is thought that the diffuse pattern is caused by residual stresses and nonuniform stolchiometry in the coat. Results after heat treatwent suggest an improvement of the crystallinity and unifornity of the zrc. The $h i g h$ value of the lattice parameter also inplles a low impurtity content and a $\mathrm{high} \mathrm{C} / \mathrm{zr}$ value.

\section{ACKNOWLEDGMENTS}

The authors acknowledge the ald of '. A. $0^{\prime}$ Rourke, L. S. Levinson, and E. A. Hakkila in analyzing the structure of the deposited coats. Without their help, there yould have been no way to know when the point of succests had been reached in the development of the powder feeder and the particle coats. He also ackuow ledge the atd of D. Yandell, Jr., In faldricat ing the powder fueder.

\section{REFERENCES}

1. K. Ikawa and $K$, Iwamoto. "Luatling Microspheras with 2rc." I. Nucl. Mater. 45.67 (1972/19/1).

2. K. Ikawa, "Vapor Depositedon of ZrC-C Composites by the lodide Process," J. l.uss-Comon Metisls 27. 325 (1972).

3. K. Ikawa, "Vapor Deposition of 2rC-C Componiless by the Chloride Process," .I. Lessu-Common Hetals 29, 233 (1972).

4. T. C. Hallace, "Cliemical Vapor Deposit tom "it $2 \mathrm{rC}$ in Small Bore Carbon-Compos le Tubes." Proc. Chem. Vap. Depasteton, Int, Conf.. 4th. 4. 91 (1973).

S. A. R. Drteriner. E. K. Stormsi, P. Hagner and T. C. Wallace. "H1gh Texperature-Low Dentity ZrC Insulators Made by Chamlcal Vapor Deporitlon." Proc. Chex. Vap. Duposittan, Int. Cint.. 4ch. 4. 473 (1973).

6. P. Hagner, "Research, Development, and Produc$t$ ion of substolchlowetric $2 \mathrm{rC}$ for $\mathrm{Mlgh}$ Temperature Insulakion." loos Alnmog Scientifte Labotatory report LA-5224 (1973).

7. K. Ikawa and $\mathrm{K}$. I vasoto. "Coac Ing Hicrospicercs with ZrC-C Composites by the Methylene Dichloride Process," J. Ceram. Aseoc. Jupan (Yogyo-Kyokai-Shi) BI. 403 (1973).

B. K. Ikawa and K. Iwawoto, "Coating MIcrospheres with 2rC-C Alloy," J. Nucl. Mater. 52, i28 (1974).

9. K. Ikava and K. Iuamoto, "Cating Mlerosphieres with ZrC-C Alloy by the lodide Process," J. Nucl. Scl. Technol. 11. 263 (1974).

10. G. H. Reynolds, "Cheralcal Vrant Deposittion of ZrC on Pyrocorbon Coated fuel Particles." J. Nucl. Mater. 50. 215 (1974).

11. R. Hartis, E, Kelley, D. H. Leeds, and H. V. Kot lensky. "Graded CVD Cont Ings for Low Thermol 1 Expansion Substraces." Proc. Chem. Vap. Deposicton, Int. Conf., 3rd, 3 183 (1972).

12. T. D. Gulden, C. L. Smith, D. P. Marnon and $H$. H. Hudritsch, "The Mechanical Design of TRISDCoated Pareficle Euels for the Large HTCR." Nucl. Technol. 16. 100 (1972).

13. C. F. Powell, I. H. Oxley, and J. M. Bladier, J... Vapor Deposition (Iohn Wiley, 1967) p. 663.

14. Brit. Pat. 967565 (1964).

15. HTGR Base Program Quarterly Progress Report, Culf Gereral Atomlc report GA-8562 p. 113 (1968).

16. J. D. Balcomb and P. Wagner, "Extending the Tempe-ature Renge of the HTR." Proc. of the British Nuclear Energ; Soclety, Int. Conf., London (1974). 